\title{
USE OF SELECTIVE MEDIUM FOR Burkholderia cepacia ISOLATION IN RESPIRATORY SAMPLES FROM CYSTIC FIBROSIS PATIENTS
}

\author{
Luiz V.F. da SILVA FILHO(1,3), Luciana de F. VELLOSO(1), Christina N.O. BENTO(2), Edelyn GYTIN(2), Adriana F. TATENO(3), José E. LEVI(3),
} Joaquim C. RODRIGUES(1) \& Sonia R.T.S. RAMOS(1)

\begin{abstract}
SUMMARY
Burkholderia cepacia colonizes cystic fibrosis (CF) patients. We evaluated the impact of the use of a selective medium in the rate of $B$. cepacia recovery from respiratory samples of CF patients. During a 6-month period, respiratory samples were collected from $106 \mathrm{CF}$ patients and cultivated on selective media including a B. cepacia selective medium. Confirmation of the identity of $B$. cepacia isolates was carried out by species specific PCR and determination of genomovar status performed by a sequential PCR approach. Results of B. cepacia isolation during this period were compared to the preceding two years, when the sample processing was identical except for the lack of the B. cepacia selective medium. B. cepacia was isolated in 11/257 (4.2\%) of the samples using the selective medium, in contrast with the preceding two years, when it was isolated in $6 / 1029$ samples $(0.58 \%)$, p < 0.0001. Identity of all 11 isolates was confirmed by PCR and genomovar determination was accomplished in all but one isolate. These results suggest that the use of a selective medium increases recovery rate of B. cepacia from respiratory samples.
\end{abstract}

KEYWORDS: Burkholderia cepacia, Selective medium, Cystic fibrosis, Sputum, Genomovars.

\section{INTRODUCTION}

Cystic fibrosis $(\mathrm{CF})$ is an inherited disease characterized by chronic obstructive lung disease, pancreatic insufficiency and elevated chloride levels in the sweat ${ }^{22,28}$. Cystic fibrosis patients are particularly susceptible to infections caused by specific bacterial pathogens such as Pseudomonas aeruginosa, Staphylococcus aureus and Haemophilus influenzae. Despite substantial advances in the prognosis due to antimicrobial therapy and early diagnosis, respiratory disease remain the first cause of death in these patients ${ }^{8}$.

Burkholderia cepacia, a plant pathogen, was identified in sputum samples from cystic fibrosis patients in the early $80 \mathrm{~s}^{13,18,23}$. In some patients, isolation of this bacteria was associated with the occurrence of a fatal necrotizing pneumonia called $B$. cepacia syndrome but in the majority of patients it caused an increase of lung function deterioration. The inherent resistance to the majority of antimicrobial drugs and further observations that $B$. cepacia strains can spread by social contact among patients, resulted in several recommendations for new approaches on microbiological surveillance ${ }^{4,25}$ and patient cohorting ${ }^{9,15}$. As a result, isolation of B. cepacia in sputum from cystic fibrosis patients carries a significant medical and psychosocial burden. Strategies for B. cepacia infection control, however, depend on the accurate identification of this pathogen on the microbiology laboratory.
B. cepacia is a fastidious gram-negative bacillus that can be difficult to isolate, since it usually grows slowly when compared to other organisms frequently found in sputum samples from $\mathrm{CF}$ patients, such as $P$. aeruginosa. B. cepacia is also difficult to identify after isolation, and misidentifications occur very frequently ${ }^{20}$. Although the use of selective media is actually recommended for B. cepacia isolation, this is not an homogenous practice among microbiology laboratories involved in the care of cystic fibrosis patients ${ }^{25}$. Furthermore, recent taxonomic analyses have demonstrated that $B$. cepacia is not an unique species, but a complex that comprises six different genomovars or genomic species ${ }^{26}$, and this characterization depends mainly on genomic analysis $2,16,17,21,29$.

In Brazil, cystic fibrosis is an underdiagnosed condition that is primarily treated at specialized (universitary) hospitals. Since the number of diagnosed patients is relatively small, there are not local guidelines for microbiological practices for culturing respiratory samples obtained from these patients, and use of selective media for $B$. cepacia isolation is not a common practice among microbiology laboratories involved in $\mathrm{CF}$ care. Approximately one hundred and ten cystic fibrosis patients attend the Pediatric Pulmonology Unit of Instituto da Criança in São Paulo, Brazil. Sputum or oropharyngeal samples of these patients are cultured monthly or bimonthly as part of the regular follow up. During a six month prospective study of direct detection of microorganisms in respiratory samples by the polymerase chain reaction (PCR), samples were also cultured in a $B$. cepacia selective medium.

(1) Instituto da Criança "Prof. Pedro de Alcântara", Hospital das Clínicas, University of São Paulo Medical School, São Paulo, Brazil.

(2) Microbiology Section of Central Laboratory, Hospital das Clínicas, University of São Paulo Medical School, São Paulo, Brazil.

(3) Laboratory of Virology, Instituto de Medicina Tropical de São Paulo, University of São Paulo Medical School, São Paulo, Brazil.

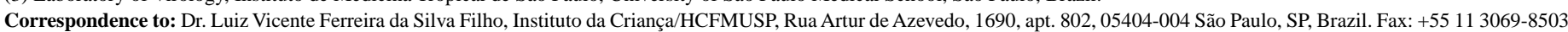
E-mail: vicres@usp.br 


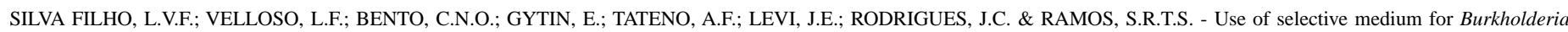
cepacia isolation in respiratory samples from cystic fibrosis patients. Rev. Inst. Med. trop. S. Paulo, 44(4):203-208, 2002.

The aim of this study was to compare the rate of isolation of $B$. cepacia during this period with the rate of isolation in the previous two years, when sample processing was identical, except for the lack of the B. cepacia selective medium. Confirmation of the identity of B. cepacia isolates was also examined by species specific $\mathrm{PCR}^{2}$, and genomovar determination was attempted by a PCR approach described by WHITBY et al. ${ }^{29}$.

\section{PATIENTS AND METHODS}

A total of 106 cystic fibrosis patients (sex: 53M:53F; age: 9m-19y, mean age $=9.77 \pm 4.83$ years) being treated at the Pediatric Pulmonology Unit of Instituto da Criança of University of São Paulo were studied from September 2000 to April 2001. Diagnosis of CF was based on clinical symptoms and two positive sweat tests or identification of two mutations by genetic analysis, according to international guidelines ${ }^{22}$.

SAMPLES: During the period of study, samples of sputum or oropharyngeal swabs from CF patients were collected on each patient visit. Sputum samples were collected directly by expectoration in a sterilized plastic receptacle, and throat swabs were collected by direct friction of a sterile cotton swab in the posterior pharynx, if possible after coughing and with concomitant use of a tongue depressor. Sputum samples were initially processed as described by WONG et al. ${ }^{30}$. Briefly, an equal volume of a sterile solution of dithithreitol (DTT) $50 \mu \mathrm{g} / \mathrm{mL}$ in phosphate buffered saline with $0.1 \%$ of gelatin was added to the sputum samples and after 30 minutes homogenized by vortexing. Oropharyngeal swabs were kept on transport medium (modified Stuart's bacterial transport medium, Beckton Dickinson, USA) until delivery to the microbiology laboratory within a short period of time (up to four hours). Written informed consent was obtained from the parents. The Ethical Committee of the Institution approved the study.

CULTURE TECHNIQUES: The samples were cultivated on blood agar (Columbia Agar - Oxoid), chocolate agar (GC Agar - Biobrás, São Paulo, Brazil), MacConkey agar (MacConkey Agar - Merck) and B. cepacia selective medium (Burkholderia cepacia medium - Oxoid), incubated at $36 \pm 1{ }^{\circ} \mathrm{C}$ for a period of 18 to 48 hours. Bacterial identification was performed with Vitek ${ }^{\circledR}$ system (bioMérieux Vitek Inc., St. Louis, Mo), using Gram-negative - GNI and Gram-positive - GPI cards, and additional biochemical tests for bacterial identification whenever necessary. Results were recorded after $24 \mathrm{~h}$ of incubation at $37{ }^{\circ} \mathrm{C}$. All isolates of $\mathrm{B}$. cepacia were transferred to tryptic soy broth (Tryptic Soy Broth - Merck ${ }^{\circledR}$ ) with $50 \%$ glycerol and stored in a $-80{ }^{\circ} \mathrm{C}$ freezer.

The results of culture of respiratory samples obtained from the same group of patients in the preceding two years were obtained by retrospective analysis of medical records. During this period, the sample processing was identical, except for the initial processing of sputum samples (addition of dithiothreitol) and the lack of B. cepacia selective medium.

DNA EXTRACTION: DNA of B. cepacia isolates was extracted by the Proteinase K - Phenol Chloroform method ${ }^{24}$. Bacterial colonies were suspended in $500 \mu \mathrm{L}$ of a solution consisting of $200 \mu \mathrm{g} / \mathrm{mL}$ Proteinase K (GIBCO-BRL Gaithesburg, FL, USA); Tris $50 \mathrm{mM} \mathrm{pH}=$ 8.0; SDS $0.5 \%$ and incubated at $56^{\circ} \mathrm{C}$ for $1 \mathrm{~h}$, then boiled for 10 minutes.
This was followed by two steps of organic extraction with PhenolChloroform (vol:vol) and DNA precipitation with 2.5 volumes of cold ethanol and 0.1 volume of sodium acetate $(3 \mathrm{M}, \mathrm{pH}=5.2)$. After centrifugation, the pellet was dried and solubilized in sterile water, and DNA was quantified in a UV spectrophotometer (UltroSpec 3000 UV/ Visible Spectrophotometer - Pharmacia, Uppsala, Sweden).

SPECIES SPECIFIC PCR: Species specific PCR was performed as described by BAUERNFEIND et al. $^{2}$, using primers Eub-16-1 (AGR GTT YGA TYM TGG CTC AG) and CeMuVi-16-2 ${ }_{457}$ (CCG RCT GTA TTA GAG CCA) targeting a 463 base pair segment of the $16 \mathrm{~S}$ ribosomal DNA of B. cepacia. Reactions were done in a final volume of $25 \mu \mathrm{L}$ containing $100 \mathrm{ng}$ of template DNA, $0.4 \mu \mathrm{M}$ of each primer, $2 \mathrm{mM}$ of $\mathrm{MgCl}_{2}, 10 \mathrm{mM}$ Tris $\mathrm{HCl}(\mathrm{pH} 8.0), 50 \mathrm{mM} \mathrm{KCl}, 250 \mu \mathrm{M}$ of dNTPs and $1 \mathrm{U}$ of Taq DNA polymerase (GIBCO-BRL Gaithesburg, FL, USA). Amplification was carried out using Mastercycler gradient thermocycler (Eppendorf) with an initial denaturation step of $94{ }^{\circ} \mathrm{C}$ for 4 minutes and 30 cycles of $94{ }^{\circ} \mathrm{C}$ for 1 minute, $56^{\circ} \mathrm{C}$ for 1 minute and $72{ }^{\circ} \mathrm{C}$ for 1 minute followed by additional 7 minutes at $72{ }^{\circ} \mathrm{C}$. Following amplification, PCR products were visualized by electrophoresis in $1.5 \%$ agarose gel stained with ethidium bromide $0.5 \mathrm{mg} / \mathrm{mL}$, with an UV transilluminator. A negative control (sample with no DNA added) was included in all PCR reactions.

PCR FOR GENOMOVAR DETERMINATION: Determination of genomovar status of B. cepacia isolates was performed according to the protocol described by WHITBY et al. ${ }^{29}$, using primers G1-G2, SPR3 and SPR4. Isolates were submitted to three separate PCR reactions with primers G1-G2, SPR3-G1 and SPR4-G1, and genomovar status was defined according to the algorithm shown in Fig. 1. PCR reactions were performed in $25 \mu \mathrm{L}$ mixtures containing $200 \mathrm{ng}$ of template DNA, 2 $\mathrm{mM}$ of $\mathrm{MgCl}_{2}, 0.8 \mu \mathrm{M}$ of each primer, $10 \mathrm{mM}$ Tris $\mathrm{HCl}(\mathrm{pH} 8.0), 50$ $\mathrm{mM} \mathrm{KCl}, 200 \mu \mathrm{M}$ of dNTPs and $1.25 \mathrm{U}$ of Taq DNA polymerase (GIBCO-BRL Gaithesburg, FL, USA). Amplification was carried out using Mastercycler gradient thermocycler (Eppendorf) with an initial denaturation step of $95{ }^{\circ} \mathrm{C}$ for 5 minutes and 30 cycles of $94{ }^{\circ} \mathrm{C}$ for 45 seconds, $66{ }^{\circ} \mathrm{C}$ for $45 \mathrm{~s}$ and $72{ }^{\circ} \mathrm{C}$ for 2 minutes followed by a final extension step at $72{ }^{\circ} \mathrm{C}$ for 10 minutes. Following amplification, PCR products were visualized by electrophoresis in $0.8 \%$ agarose gel stained with ethidium bromide $0.5 \mathrm{mg} / \mathrm{mL}$, with an UV transilluminator. A negative control (sample with no DNA added) was included in all PCR reactions.

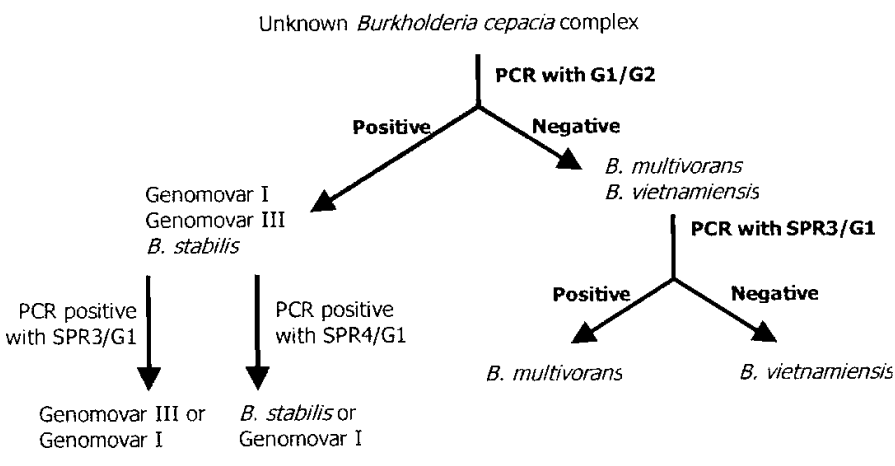

Fig. 1 - PCR algorithm to identify the species and genomovars of the B. cepacia complex. Reproduced from WHITBY et al. ${ }^{29}$. 
STATISTICAL ANALYSIS: The results of B. cepacia isolation during the six month period were compared to the results of preceding two years, when the sample processing was identical except for the lack of a . cepacia selective media. Comparisons between the results of the two periods used $\chi^{2}$ test or two-tailed Fisher exact test, and a p value < 0.05 was considered significant.

\section{RESULTS}

During the six month study period, a total of 257 samples were cultured. B. cepacia was isolated in 11/257 (4.2\%) of the samples using the $B$. cepacia selective medium. Cultures were obtained from 9 sputum samples and two oropharyngeal swabs, from 8 patients aged 11 months to 17 years old. In the two years preceding the start of the study, $B$. cepacia was isolated in $6 / 1029$ samples $(0.58 \%)$, from 5 patients aged 7 to 16 years old. The difference in the rate of isolation among the two

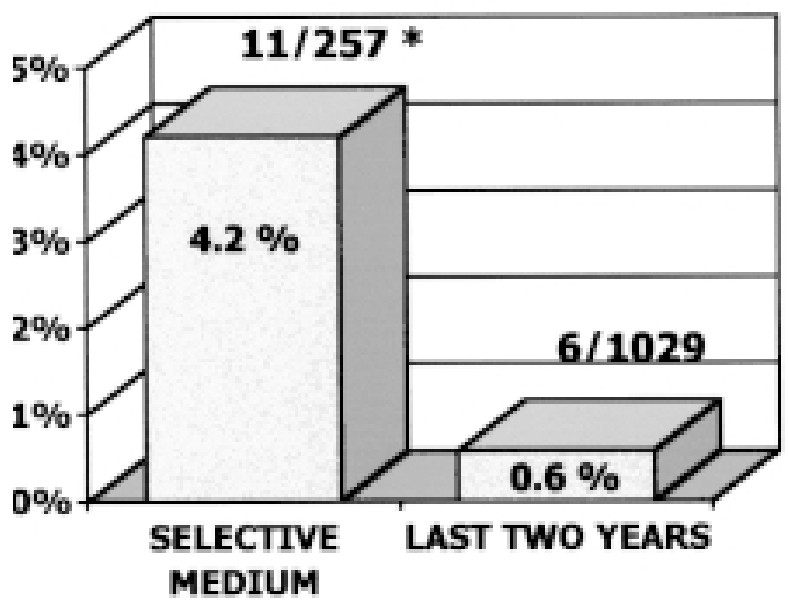

Fig. 2 - Graphical representation of the rate of isolation of B. cepacia in the two periods studied. * two-tailed Fisher exact test: $p<0.0001$. periods, $11 / 257(4.2 \%)$ versus $6 / 1029(0.6 \%)$ was statistically significant (two-tailed Fisher exact test, $\mathrm{p}<0.0001$ ), Fig. 2. However, the number of patients characterized as colonized by B. cepacia (i.e., with at least one sample positive for the bacterium) was not significantly different when the two periods were compared (8/106 (7.5\%) versus 5/106 (4.7\%), $\chi^{2}$ test: $\mathrm{p}=0.39$ )

The identity of the 11 isolates of B. cepacia was confirmed by species specific PCR, with all isolates tested resulting in a 463 bp amplicon resultant of amplification of the $16 \mathrm{~S}$ ribosomal DNA of B. cepacia, as partially shown in Fig. 3.

The application of the PCR protocol for B. cepacia genomovar determination classified two strains as Burkholderia vietnamiensis, two strains as Burkholderia multivorans and 4 strains as belonging to genomovars I or III, as shown in Table 1 and illustrated in Fig. 4. PCR reactions resulted in the amplification of DNA fragments of approximately $1.3 \mathrm{~kb}$ in at least one of the combination of the three primers in all but two samples, which were assigned as B. vietnamiensis.

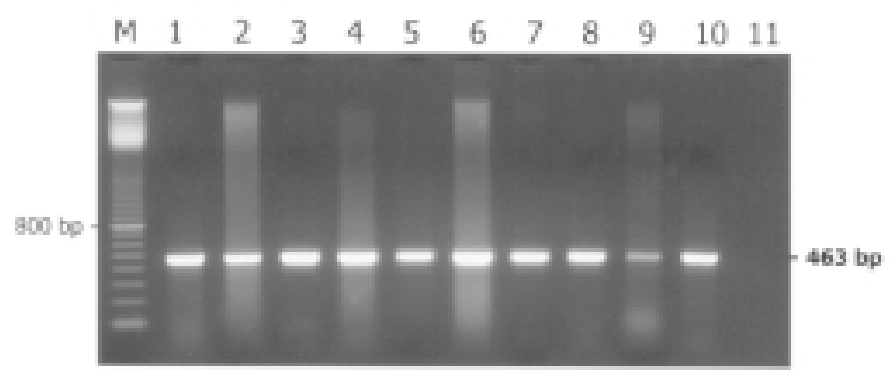

Fig. 3 - Species specific PCR of representative B. cepacia strains with primers Eub-16-1/ CeMuVi-16-2 457 .

Lane 1: B. cepacia strain obtained from the microbiology laboratory repository. Lanes 2 to 10: nine representative strains of $B$. cepacia isolated during the six month study period. Lane 11: negative control (no DNA added). M: molecular weight marker (100 bp ladder, Pharmacia, Upsalla, Sweden).

Table 1

PCR results of B. cepacia complex genomovar determination, using primers G1, G2, SPR3 and SPR4, as described by WHITBY et al. ${ }^{29}$. Patient names are indicated by assorted initials. PCR results are expressed: +, positive PCR; -, negative PCR

\begin{tabular}{|c|c|c|c|c|c|c|}
\hline \multirow[b]{2}{*}{ Sample } & \multirow[b]{2}{*}{$\begin{array}{c}\text { Date of } \\
\text { isolation }\end{array}$} & \multirow[b]{2}{*}{ Patient } & \multicolumn{3}{|c|}{ PRIMER PAIRS } & \multirow[b]{2}{*}{$\begin{array}{l}\text { Genomovar / } \\
\text { Subspecies }\end{array}$} \\
\hline & & & $\mathrm{G} 1 / \mathrm{G} 2$ & SPR3/G1 & SPR4/G1 & \\
\hline 6 & $9 / 27 / 2000$ & SL & - & - & - & B. vietnamiensis \\
\hline 21 & $10 / 5 / 2000$ & $\mathrm{ABL}$ & - & + & - & B. multivorans \\
\hline 106 & $12 / 18 / 2000$ & $\mathrm{ABL}$ & - & + & - & B. multivorans \\
\hline 29 & $10 / 16 / 2000$ & CLO & + & + & - & Genomovar III (or I) \\
\hline 176 & $2 / 7 / 2001$ & CLO & + & + & - & Genomovar III (or I) \\
\hline 55 & $10 / 30 / 2000$ & OCR & + & + & - & Genomovar III (or I) \\
\hline 130 & $1 / 10 / 2001$ & THC & + & + & - & Genomovar III (or I) \\
\hline 157 & $1 / 24 / 2001$ & THC & + & + & - & Genomovar III (or I) \\
\hline 137 & $1 / 15 / 2001$ & $\mathrm{NCC}$ & + & + & - & Genomovar III (or I) \\
\hline 177 & $2 / 7 / 2001$ & SFRV & + & - & - & Undetermined \\
\hline 220 & $3 / 14 / 2001$ & SAG & - & - & - & B. vietnamiensis \\
\hline
\end{tabular}




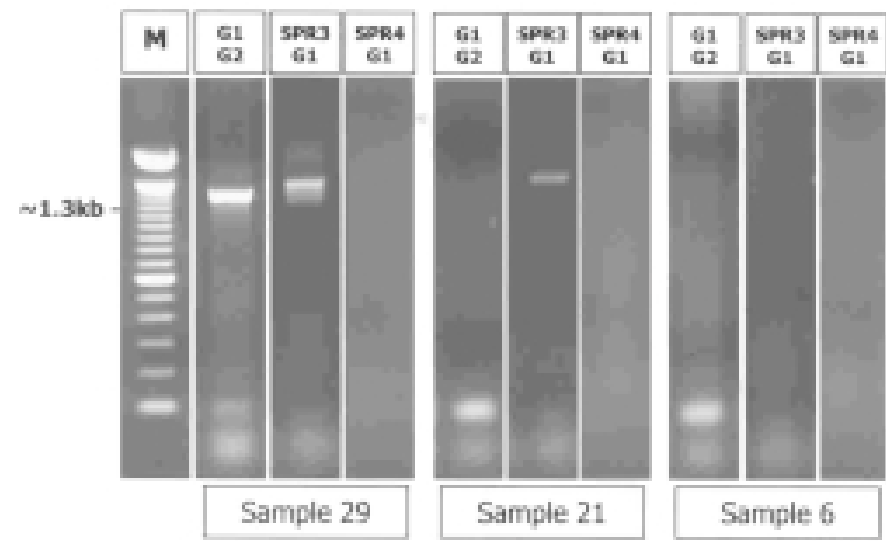

Fig. 4 - PCR for B. cepacia complex genomovar determination, as described by WHITBY et al. ${ }^{29}$. Expected size of amplicons for each primer pair: $1.3 \mathrm{~kb}$.

Each lane represents PCR products obtained with the primer pair indicated on the top; sample 29 was assigned as B. cepacia genomovar III (or I); sample 21 as B. multivorans and sample 6 as B. vietnamiensis. M: molecular weight marker (100 bp ladder, Pharmacia, Upsalla, Sweden).

We didn't observe PCR products using the primers G1-SPR4 in any of the strains tested (Table 1), and therefore we did not identify strains of B. stabilis or B. cepacia genomovar I. The genomovar status of one isolate could not be determined, as it didn't result in PCR products of the expected size with primer pair G1-SPR3 while showed positive result with primer pair G1-G2, an unexpected event.

\section{DISCUSSION}

B. cepacia is a microorganism that has great significance in cystic fibrosis. Since its recognition as an infecting agent in $\mathrm{CF}$ patients in the mid 80s, much have been learned about its importance, transmission and clinical impact, but several questions remain to be answered. The isolation of this organism in respiratory secretions of CF patients still carry a severe psychosocial burden, arising from the precautions to minimize person-to-person transmission and to the increased rates of morbidity and mortality in this patient population ${ }^{15}$.

Pseudomonas cepacia was originally described by Burkholder in 1950 as the causative agent of bacterial rot of onion bulbs. In 1992, $P$. cepacia was transferred to the new genus Burkholderia, which currently include 22 bacterial species ${ }^{7}$. Several additional modifications in the taxonomy of $B$. cepacia have occurred in the last decade, with the recognition of marked heterogeneity among $B$. cepacia strains isolated from different echological niches. B. cepacia was classified as a complex, comprising at least five different genomic species or genomovars ${ }^{26} . B$. cepacia genomovar $\mathrm{V}$ was identified as the previously described species $B$. vietnamiensis ${ }^{7}$ and the name $B$. multivorans was proposed for strains belonging to the genomovar II. B. cepacia genomovar IV was subsequently classified as $B$. stabili ${ }^{27}$. Recent taxonomic studies identified more three members of $B$. cepacia complex, B. cepacia genomovar VI, B. ambifaria and B. pyrrocinia ${ }^{1,5,6}$.

Clinical management of respiratory infections in CF patients rely on the identification of organisms cultured from respiratory specimens such as sputum, oropharyngeal swabs or bronchoalveolar lavage samples, but this apparently simple procedure may not be straightforward. Identification of B. cepacia can be problematic and misidentifications may be relatively common. As many as $20 \%$ of isolates sent to reference laboratories identified as B. cepacia may be misidentified ${ }^{20}$. Therefore, the use of a selective media that take advantage of the species broad antibiotic resistance is a critical first step in sample processing.

A comparison of three media was performed by HENRY et al. ${ }^{11}$, reporting superiority of BCSA (B. cepacia selective agar) to OFPBL and PCA (P. cepacia medium) in terms of rapidity and quality of recovery of $B$. cepacia complex organisms from CF respiratory specimens, while inhibiting the growth of other organisms. The above mentioned medium (BCSA), however, is not indicated for isolation of environmental $B$. cepacia isolates, due to low specificity/sensitivity.

We utilized a different medium, named B. cepacia medium (Oxoid), mainly indicated for the isolation and identification of $B$. cepacia from respiratory secretions of $\mathrm{CF}$ patients. As expected, a significant difference of isolation rates of B. cepacia strains was observed among the two periods analyzed (with and without the use of selective medium), which was probably derived from the discriminating properties of the B. cepacia selective medium. Although there was a significant difference in the rate of $B$. cepacia isolation, the use of the selective medium did not contribute to identification of a significant broader patient population colonized with $B$. cepacia, but isolation of B. cepacia was observed in younger patients and in two oropharyngeal swabs samples. The impact of the use of dithiothreitol (DTT) as a solubilizing agent in culture results was previously assessed by HAMMERSCHLAG et al., who showed that the substance may interfere in the isolation rate of $H$. influenzae only when high concentrations were used ${ }^{10}$. Although this aspect was not specifically addressed in the present work, it seems unlikely that the use of DTT as part of initial sample processing had some influence in the observed results.

Although there are recommendations for specific microbiological practices when culturing samples from CF patients, they are not universally adopted, even in more specialized laboratories. The situation in Brazil is quite different, since there are few specialized centers for $\mathrm{CF}$ care and there is no information or consensus for the microbiology practices used for culturing respiratory samples obtained from $\mathrm{CF}$ patients.

The use of PCR for the identification of B. cepacia strains was described by a number of authors ${ }^{3,14}$, but the taxonomic changing of the Burkholderia genus have posed new potential caveats associated with some primer pairs described, such as cross reactivity with non-B.cepacia complex organisms or poor specificity for the identification of some of the species ${ }^{16,19}$. To date, the only described primer pairs that are supposed to identify all members of the $B$. cepacia complex are those described by BAUERNFEIND et al. ${ }^{2}$, Eub-16-1/ CeMuVi-16- $2_{457}$, which identify genomovars I, III, B. multivorans, B. vietnamiensis and B. stabilis, and primers BCR1/BCR2, described by MAHENTHIRALINGAM et al. ${ }^{17}$, which are able to identify all members of the B. cepacia complex, including the very recently described $B$. cepacia genomovar VI and genomovar VII (B. ambifaria $)^{17,19}$.

We decided to use the primer pair described by BAUERNFEIND et al., since it is currently being tested by our group for direct detection of 


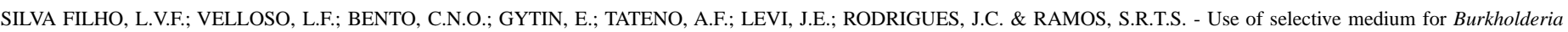
cepacia isolation in respiratory samples from cystic fibrosis patients. Rev. Inst. Med. trop. S. Paulo, 44(4):203-208, 2002.

B. cepacia strains in respiratory samples from $\mathrm{CF}$ patients. Our PCR results with this primer pair confirmed the identity of all the eleven $B$. cepacia strains isolated with the selective medium. This primer pair was also tested in PCR reactions with DNA of other bacterial species frequently found in the sputum of CF patients ( $P$. aeruginosa, S. aureus, $H$. influenzae, $S$. maltophilia), and didn't result in any visible PCR product (data not shown).

The knowledge of B. cepacia complex genomovar species responsible for respiratory infections in CF patients is extremely important for appropriate segregation and grouping of CF patients into cohorts $^{15,19}$. Although there are now recent described phenotypic tests for genomovar determination, it is still not possible to identify all genomovars based on this approach ${ }^{12}$. Several strategies have been proposed for the identification of genomovars using molecular biology techniques, and the method described by WHITBY et al. ${ }^{29}$ was chosen because of its simplicity, although it is not able to differentiate genomovars I and III. Since CF patients are predominantly colonized by genomovar III and B. multivorans ${ }^{16,19,26}$, this limitation doesn't constitute a significant pitfall. The results obtained with the PCR approach using primers G1, G2, SPR3 and SPR4 confirmed this predominance of genomovar III (most likely) among our CF patients, although we found the same proportion of patients colonized by $B$. multivorans and $B$. vietnamiensis (two patients colonized with each species). Three patients have two B. cepacia positive cultures, obtained on different dates; none of them, however, presented different genomovars.

In summary, our results confirmed the importance of the use of a selective medium for $B$. cepacia isolation when culturing respiratory samples from cystic fibrosis patients. We have also confirmed the identity of all isolates of B. cepacia by species specific PCR and further characterized these isolates by genomovar status, obtaining results similar to those described on other CF specialized Centers.

\section{ACKNOWLEDGEMENTS}

We thank Mrs. Silvana Fernandes for technical support on DNA extractions. We also thank all the medical staff of the Pediatric Pulmonology Unit of Instituto da Criança, São Paulo, Brazil, for their assistance during patients attendance. This work was supported by FAPESP, grant 1999/00067-9. The author (LVFSF) was sponsored by CAPES, Brazil.

\section{RESUMO}

Uso de meio seletivo para identificação de cepas de Burkholderia cepacia em amostras de trato respiratório de pacientes portadores de fibrose cística

A Burkholderia cepacia coloniza os pacientes portadores de fibrose cística (FC). Avaliamos o impacto do uso de um meio seletivo no isolamento de B. cepacia em amostras de secreção respiratória de pacientes portadores de FC. Durante um período de 6 meses, amostras de trato respiratório foram colhidas de 106 pacientes com FC e cultivadas em meios seletivos incluindo um meio para isolamento de B. cepacia. A identidade das cepas de $B$. cepacia foi confirmada através de PCR espécie específica e a determinação do genomovar ou subespécie realizada através de reações seqüenciais de PCR. Os resultados de isolamento de B. cepacia durante este período foram comparados com os dois anos precedentes, quando o processamento das amostras era idêntico, exceto pela utilização do meio seletivo para B. cepacia. B. cepacia foi isolada em 11/257 (4,2\%) amostras usando o meio seletivo, e em apenas 6/1029 (0,58\%) nos dois anos precedentes $(\mathrm{p}<0,0001)$. A identidade destas 11 cepas foi confirmada e a determinação do genomovar obtida em 10/11. Estes resultados sugerem que o uso do meio seletivo aumenta a frequiência de isolamento de B. cepacia em amostras de trato respiratório de pacientes portadores de FC.

\section{REFERENCES}

1.BALANDREAU, J.; VIALLARD, V.; COURNOYER, B. et al. - Burkholderia cepacia genomovar III is a common plant-associated bacterium. Appl. environ. Microbiol., 67: 982-985, 2001.

2. BAUERNFEIND, A.; SCHNEIDER, I.; JUNGWIRTH, R. \& ROLLER, C. Discrimination of Burkholderia multivorans and Burkholderia vietnamiensis from Burkholderia cepacia genomovars I, III, and IV by PCR. J. clin. Microbiol., 37: 1335-1339, 1999.

3. CAMPBELL $3^{\text {rd }}$, P.W.; PHILLIPS $3^{\text {rd }}$ J.A.; HEIDECKER, G.J. et al. - Detection of Pseudomonas (Burkholderia) cepacia using PCR. Pediat. Pulmonol., 20: 44-49, 1995.

4. CIMOLAI, N.; TROMBLEY, C.; DAVIDSON, A.G. \& WONG, L.T. - Selective media for isolation of Burkholderia (Pseudomonas) cepacia from the respiratory secretions of patients with cystic fibrosis. J. clin. Path., 48: 488-490, 1995.

5. COENYE, T.; LIPUMA, J.J.; HENRY, D. et al. - Burkholderia cepacia genomovar VI, a new member of the Burkholderia cepacia complex isolated from cystic fibrosis patients. Int. J. system. evol. Microbiol., 51: 271-279, 2001.

6. COENYE, T.; MAHENTHIRALINGAM, E.; HENRY, D. et al. - Burkholderia ambifaria $s p$. nov., a novel member of the Burkholderia cepacia complex including biocontrol and cystic fibrosis-related isolates. Int. J. system. evol. Microbiol., 51: 1481-1490, 2001.

7. COENYE, T.; VANDAMME, P.; GOVAN, J.R. \& LiPUMA, J.J. - Taxonomy and identification of the Burkholderia cepacia complex. J. clin. Microbiol., 39: 34273436,2001

8. CYSTIC FIBROSIS FOUNDATION - Patient Registry 1999 annual data report. Bethesda, Cystic Fibrosis Foundation, 2000.

9. GOVAN, J.R. - Infection control in cystic fibrosis: methicillin-resistant Staphylococcus aureus, Pseudomonas aeruginosa and the Burkholderia cepacia complex. J. roy. Soc. Med., 93(suppl 38): 40-45, 2000

10. HAMMERSCHLAG, M.R.; HARDING, L.; MACONE, A.; SMITH, A.L. \& GOLDMANN, D.A. - Bacteriology of sputum in cystic fibrosis: evaluation of dithiothreitol as a mucolytic agent. J. clin. Microbiol., 11: 552-557, 1980.

11. HENRY, D.; CAMPBELL, M.; MCGIMPSEY, C. et al. - Comparison of isolation media for recovery of Burkholderia cepacia complex from respiratory secretions of patients with cystic fibrosis. J. clin. Microbiol., 37: 1004-1007, 1999.

12. HENRY, D.A.; MAHENTHIRALINGAM, E.; VANDAMME, P.; COENYE, T. \& SPEERT, D.P. - Phenotypic methods for determining genomovar status of the Burkholderia cepacia complex. J. clin. Microbiol., 39: 1073-1078, 2001.

13. ISLES, A.; MACLUSKY, I.; COREY, M. et al. - Pseudomonas cepacia infection in cystic fibrosis: an emerging problem. J. Pediat., 104: 206-210, 1984.

14. KARPATI, F. \& JONASSON, J. - Polymerase chain reaction for the detection of Pseudomonas aeruginosa, Stenotrophomonas maltophilia and Burkholderia cepacia in sputum of patients with cystic fibrosis. Molec. cell Probes, 10: 397-403, 1996. 
SILVA FILHO, L.V.F.; VELLOSO, L.F.; BENTO, C.N.O.; GYTIN, E.; TATENO, A.F.; LEVI, J.E.; RODRIGUES, J.C. \& RAMOS, S.R.T.S. - Use of selective medium for Burkholderia cepacia isolation in respiratory samples from cystic fibrosis patients. Rev. Inst. Med. trop. S. Paulo, 44(4):203-208, 2002.

15. LIPUMA, J.J. - Burkholderia cepacia. Management issues and new insights. Clin. Chest Med., 19: 473-86, vi, 1998.

16. LiPUMA, J.J.; DULANEY, B.J.; McMENAMIN, J.D. et al. - Development of rRNAbased PCR assays for identification of Burkholderia cepacia complex isolates recovered from cystic fibrosis patients. J. clin. Microbiol., 37: 3167-3170, 1999.

17. MAHENTHIRALINGAM, E.; BISCHOF, J.; BYRNE, S.K. et al. - DNA-based diagnostic approaches for identification of Burkholderia cepacia complex, Burkholderia vietnamiensis, Burkholderia multivorans, Burkholderia stabilis, and Burkholderia cepacia genomovars I and III. J. clin. Microbiol., 38: 3165-3173, 2000.

18. MARQUES, E.; PINTO, R.M.; DALLALLANA, L.T. et al. - Isolation of Pseudomonas cepacia in cystic fibrosis patient. Mem. Inst. Oswaldo Cruz, 88: 125-129, 1993.

19. McDOWELL, A.; MAHENTHIRALINGAM, E.; MOORE, J.E. et al. - PCR-based detection and identification of Burkholderia cepacia complex pathogens in sputum from cystic fibrosis patients. J. clin. Microbiol., 39: 4247-4255, 2001

20. McMENAMIN, J.D.; ZACCONE, T.M.; COENYE, T.; VANDAMME, P. \& LiPUMA, J.J. - Misidentification of Burkholderia cepacia in US cystic fibrosis treatment centers: an analysis of 1,051 recent sputum isolates. Chest, 117: 1661-1665, 2000.

21. MOORE, J.E.; MILLAR, B.C.; JIRU, X. et al. - Rapid characterization of the genomovars of the Burkholderia cepacia complex by PCR-single-stranded conformational polymorphism (PCR-SSCP) analysis. J. Hosp. Infect., 48: 129-134, 2001.

22. ROSENSTEIN, B.J. \& CUTTING, G.R. - The diagnosis of cystic fibrosis: a consensus statement. Cystic Fibrosis Foundation Consensus Panel. J. Pediat., 132: 589-595, 1998.
23. ROSENSTEIN, B.J. \& HALL, D.E. - Pneumonia and septicemia due to Pseudomonas cepacia in a patient with cystic fibrosis. Johns Hopkins. med. J., 147: 188-189, 1980.

24. SAMBROOK, J.; FRITSCH, E. \& MANIATIS, T. - Molecular cloning: a laboratory manual. 2. ed. Cold Spring, Cold Spring Harbor Lab., 1989.

25. SHREVE, M.R.; BUTLER, S.; KAPLOWITZ, H.J. et al. - Impact of microbiology practice on cumulative prevalence of respiratory tract bacteria in patients with cystic fibrosis. J. cin. Microbiol., 37: 753-757, 1999.

26. VANDAMME, P.; HOLMES, B.; VANCANNEYT, M. et al. - Occurrence of multiple genomovars of Burkholderia cepacia in cystic fibrosis patients and proposal of Burkholderia multivorans sp. nov. Int. J. system. Bact., 47: 1188-1200, 1997.

27. VANDAMME, P.; MAHENTHIRALINGAM, E.; HOLMES, B. et al. - Identification and population structure of Burkholderia stabilis sp. nov. (formerly Burkholderia cepacia genomovar IV). J. clin. Microbiol., 38: 1042-1047, 2000.

28. WELSH, M.J. \& SMITH, A.E. - Cystic fibrosis. Sci. Amer., 273: 52-59, 1995.

29. WHITBY, P.W.; CARTER, K.B.; HATTER, K.L.; LiPUMA, J.J. \& STULL, T.L. Identification of members of the Burkholderia cepacia complex by species-specific PCR. J. clin. Microbiol., 38: 2962-2965, 2000.

30. WONG, K.; ROBERTS, M.C.; OWENS, L.; FIFE, M. \& SMITH, A.L. - Selective media for the quantitation of bacteria in cystic fibrosis sputum. J. med. Microbiol., 17: 113-119, 1984.

Received: 14 March 2002

Accepted: 13 June 2002 